\title{
Light-activated disinfection in endodontics: A comprehensive review
}

\author{
Saad Haroon ${ }^{1, A, D-F}$, Abdul Khabeer ${ }^{2, B, C, E, F}$, Muhammad Ali Faridi ${ }^{2, D-F}$ \\ ${ }^{1}$ Department of Dentistry, Muaither Health Center, Primary Healthcare Cooperation (PHCC), Doha, Quatar \\ ${ }^{2}$ Department of Restorative Dental Sciences, College of Dentistry, Imam Abdulrahman Bin Faisal University, Dammam, Saudi Arabia \\ A - research concept and design; $\mathrm{B}$ - collection and/or assembly of data; $\mathrm{C}$ - data analysis and interpretation; \\ $D$ - writing the article; $E$ - critical revision of the article; $F$ - final approval of the article
}

Address for correspondence

\section{Abdul Khabeer}

E-mail:akhabz@hotmail.com

Funding sources

None declared

Conflict of interest

None declared

Acknowledgements

The authors would like to thank Dr. Ali Saeed

for his valuable feedback.

Received on 0ctober 16, 2020

Reviewed on February 20, 2021

Accepted on March 3, 2021

Published online on September 30, 2021

Cite as

Haroon S, Khabeer A, Faridi MA. Light-activated disinfection

in endodontics: A comprehensive review. Dent Med Probl.

2021;58(3):411-418. doi:10.17219/dmp/133892

DOI

$10.17219 / \mathrm{dmp} / 133892$

Copyright

( 2021 by Wroclaw Medical University

This is an article distributed under the terms of the

Creative Commons Attribution 3.0 Unported License (CC BY 3.0)

(https://creativecommons.org/licenses/by/3.0/)

\begin{abstract}
Light-activated disinfection (LAD) has emerged as a novel approach toward antimicrobial disinfection within the root canal. This approach is based on the concept that porphyrins and photosensitizers (PSS) can be activated by light to produce cytotoxic elements that induce the desired therapeutic effect. Unlike antibiotics, LAD can act on multiple targets within a bacterial cell, including membrane lipids, genomic DNA and various proteins, including enzymes, thus reducing the ability of the organism to acquire resistance.

The aim of this review was to develop an understanding of the potential use of $L A D$ in endodontics and to suggest strategies to maximize the antibacterial effects of LAD.

The electronic searches of the PubMed/MEDLINE, Web of Science, Scopus, and Cochrane databases were complemented by a manual hand search. A total of 303 studies were evaluated for essential parameters, which included the origin, types/variations, methodology, and application of LAD in in vitro and in vivo studies.

It can be concluded that $L A D$ is effective against the vast majority of bacterial pathogens, including antibioticresistant Gram-negative and Gram-positive bacteria, along with several yeasts, viruses and protozoan species. The literature tends to suggest that LAD can be used either as a substitute or an adjunct to the conventional antimicrobial treatment regimens that are implemented to battle polymicrobial biofilms.
\end{abstract}

Keywords: biofilms, disinfection, light-activated disinfection, photosensitizing agents, root canal therapy 


\section{Introduction}

There are over 700 microbial species that can be present in the oral cavity, and an individual can have 100-200 species at any given time. ${ }^{1}$ Usually, primary root canal infections are polymicrobial in nature and are dominated by anaerobic bacterial species. ${ }^{2}$ The organisms frequently isolated in such cases include Gram-negative anaerobic rods, Gram-positive anaerobic cocci, gram-positive anaerobic and facultative rods, Lactobacillus, and Streptococcus spp..$^{2}$ Most anaerobes are easy to eliminate during root canal treatment, but facultative bacteria may survive the disinfection procedures. ${ }^{2}$ Enterococcus faecalis is the microorganism that has been isolated in most cases of failed root canal treatment, and has therefore been mentioned in the literature as one of the chief causative agents. ${ }^{3}$ Along with E. faecalis, Staphylococcus, Enterococcus, Enterobacter, Bacillus, Pseudomonas, Stenotrophomonas, Sphingomonas, Candida, and Actinomyces spp. have also been isolated from root-filled teeth with posttreatment disease. ${ }^{4-9}$ Antibacterial agents are widely used in the treatment of bacterial infections, but the emergence of bacterial pathogens resistant to the commonly used chemotherapeutics has led to a search for alternative drugs and/or therapies to overcome the development of resistant species.

Sodium hypochlorite $(\mathrm{NaOCl})$ is the gold standard for endodontic disinfectants, ${ }^{10}$ as it has the ability to dissolve tissue and provide broad-spectrum antimicrobial effects, ${ }^{11}$ making it the solution of choice for the treatment of pulp necrosis and infection. ${ }^{12}$ However, this disinfectant has several undesirable drawbacks, such as the risk of tissue damage, allergic potential, and unpleasant smell and taste. Although other irrigants, such as chlorhexidine, are more compatible than $\mathrm{NaOCl}$, they lack the tissue dissolving ability; thus, their activity is greatly reduced when exposed to organic matter. ${ }^{13}$ Several other irrigants have been used for endodontic disinfection, but have been found to be inferior to or equally effective as (with regard to bactericidal properties) $\mathrm{NaOCl} .{ }^{14}$

These drawbacks have forced a major research effort to find alternative antimicrobial approaches aimed at killing microorganisms without causing resistance. The concept of light-based disinfection as a means of eliminating the bacterial microflora from within the root canal was described by Foote. ${ }^{15}$ Light-activated disinfection (LAD) has emerged as a novel approach toward antimicrobial disinfection within the root canal. ${ }^{16}$ It is based on the concept that porphyrins and photosensitizers (PSs) can be activated by light to produce cytotoxic elements that induce the desired therapeutic effect. ${ }^{16}$ Light-activated disinfection can act on multiple targets within a bacterial organism. These target sites include the lipid membrane, genomic DNA and various proteins, including enzymes. This, in turn, reduces the ability of the organism to acquire resistance against LAD. ${ }^{16}$
The aim of this review was to develop an understanding of the potential use of LAD in endodontics and to suggest strategies to maximize the antimicrobial effects of this technique.

\section{Methodology}

The electronic searches of the PubMed/MEDLINE, Web of Science, Scopus, and Cochrane databases were carried out. A total of 303 studies were evaluated for essential parameters, which included the origin, types/variations, methodology, and application of LAD, along with the potential risk factors reported in in vitro and in vivo studies. The searches were carried out using the combinations of the following keywords: "microbial infections"; "porphyrins"; "photosensitization"; "activated oxygen"; "bacterial infections/therapy"; "phototherapy"; "diode laser"; "blue light"; and "wavelength 450-670 nm". After the initial screening, a total of 80 articles were selected. The electronic searches were complemented by a manual search of various textbooks and articles. A total of 7 articles were identified as a result of the manual search. In total, 87 articles were considered relevant and used for this project (Fig. 1).

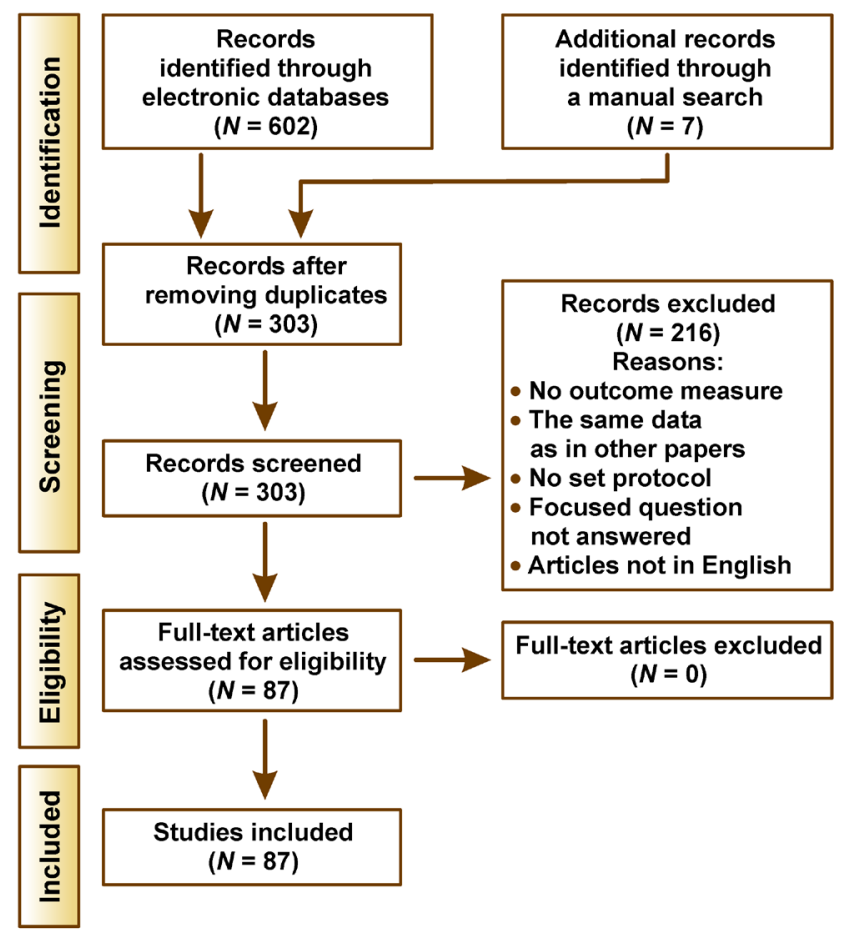

Fig. 1. PRISMA (Preferred Reporting Items for Systematic Reviews and MetaAnalyses) flow diagram showing the literature search and the selection criteria According to: Moher D, Liberati A, Tetzlaff J, Altman DG; PRISMA Group. Preferred Reporting Items for Systematic Reviews and Meta-Analyses: The PRISMA statement.

PLoS Med. 2009;6(7):e1000097. doi:10.1371/journal.pmed.1000097. For further information, visit http://www.prisma-statement.org/. 


\section{Light-activated disinfection in endodontics}

Light-activated disinfection starts when the porphyrins or PSs are exposed to a specific wavelength of light, within the target tissue, leading to the production of singlet oxygen $\left({ }^{1} \mathrm{O}_{2}\right)$, being the main reactive oxygen species (ROS) (Fig. 2).

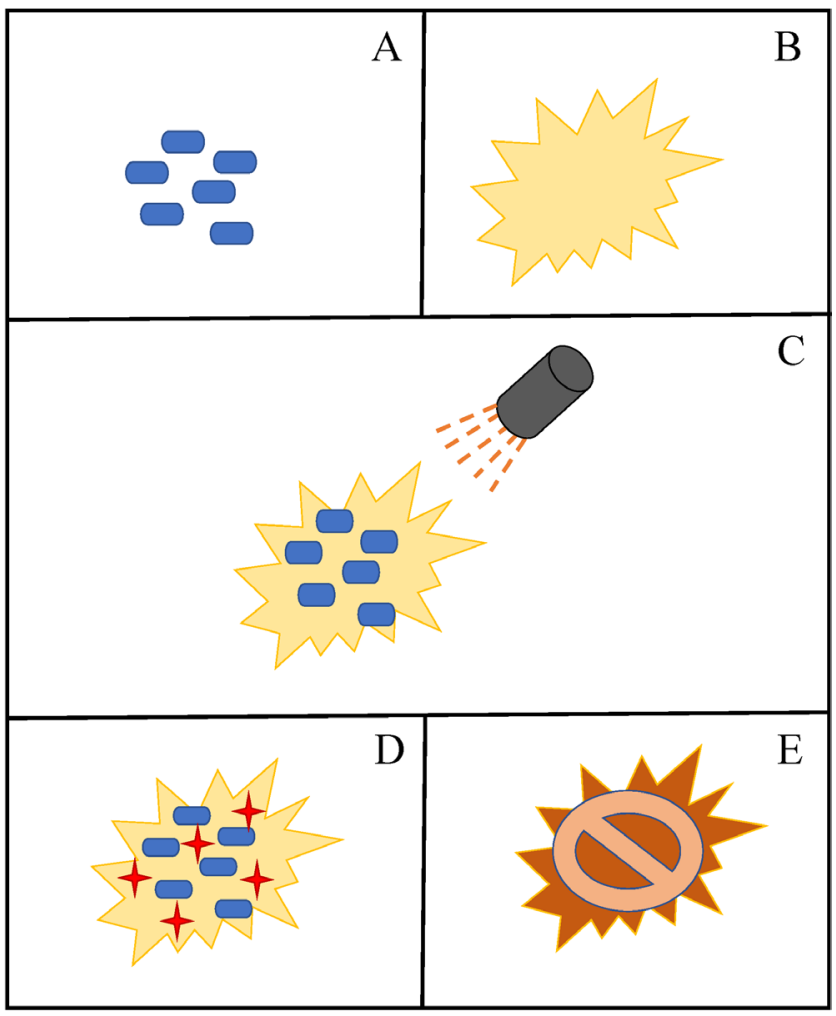

Fig. 2. Mechanism of action of light-activated disinfection (LAD) on a bacterial cell

A - photosensitizer (PS) molecules; B - bacterial cell; C - PS entering the bacterial cell, followed by activation with the use of light of a specific wavelength; D - production of reactive oxygen species (ROS); E - cell death.

\section{Effect on bacterial biofilms}

Most of the laboratory and clinical investigations using the LAD technique within the root canal use a PS rather than bacterial porphyrins. Photosensitizers are chemical derivatives of the naturally occurring porphyrins within the specific species. The effective elimination of both Streptococcus mutans and E. faecalis has been reported with a combination of LAD and either methylene blue (MB) or toluidine blue $\mathrm{O}$ (TBO), with a killing efficacy of $97-99.9 \%$ for planktonic bacterial loads of up to 10 million organisms at an exposure time of 120 s. ${ }^{17}$ Relatively similar results have been reported for the elimination of Staphylococcus intermedius, with complete kills for loads of up to 1,000 million organisms within the root canal, using TBO as a dye and a helium-neon (He-Ne) laser of an output power of $35 \mathrm{~mW}$, when exposed for $150 \mathrm{s.}{ }^{18}$ When E. faecalis is used as the infecting organism, there is a reported $77.5 \%$ killing rate with a combination of $\mathrm{MB}$ and a diode laser at a fluence level of $60 \mathrm{~J} / \mathrm{cm}^{2}, 99.9 \%$ with TBO and a laser of an output power of $50 \mathrm{~mW}$ at an energy level of $6.4 \mathrm{~J},{ }^{19}$ and $90 \%$ killing ex vivo and $99.99 \%$ killing in vitro while using a combination of TBO and a diode laser of an output power of $100 \mathrm{~mW}$ at an energy level of 15 J. ${ }^{20}$ According to George and Kishen, 99.99\% elimination of E. faecalis biofilms could be achieved by using $\mathrm{MB}$ and a $30 \mathrm{~mW}$ diode laser set at $36 \mathrm{~J} .{ }^{21}$ By applying a dual-stage approach (a modified PS formulation and an irradiation medium), they managed to achieve disinfection without canal enlargement. This procedure was termed "advanced non-invasive light-activated disinfection" or ANILAD. ${ }^{21}$ The use of LAD has also been shown to be effective against Prevotella intermedia, Peptostreptococcus micros, Fusobacterium nucleatum, Porphyromonas spp., and Actinomyces spp. ${ }^{21}$

Studies have also shown the effectiveness of LAD in eradicating mixed biofilm infections. Fimple et al. suggested that, when combined with $\mathrm{MB}$, diode lasers could cause a $73-80 \%$ reduction in multi-species bacterial biofilm loads. ${ }^{22}$ An in vitro study by Soukos et al. on planktonic biofilms showed that all microorganisms were eliminated following MB-mediated LAD, except $E$. faecalis, which showed only a $47 \%$ reduction. ${ }^{23}$ However, the authors did report a $97 \%$ reduction of E. faecalis on E. faecalis-based biofilms afterward. The authors suggested that the variation was due to a difference in susceptibility toward much higher energy fluence for LAD that was being used. ${ }^{23}$ In another study, Williams et al. compared the sensitivity of planktonic microorganisms against the biofilms grown in root canals and Perspex ${ }^{\circledR}$ simulated canals. ${ }^{24}$ The specimens were exposed to a combination of LAD with TBO. The results indicated that LAD was less effective in root canals than in the suspension form. The study did not run a comparison for single species within the planktonic and biofilm mode of growth. ${ }^{24}$ It should also be noted that clinically, most acute exacerbations during endodontic treatment involve the Porphyromonas bacterial species, ${ }^{25}$ in particular P. endodontalis, an anaerobe that is highly susceptible to ${ }^{1} \mathrm{O}_{2}$.

\section{Use of LAD with the existing irrigation methods}

Light-activated disinfection should be used in conjunction with the existing measures of irrigation, such as the use of $\mathrm{NaOCl}$. In a study by Bonsor et al., 14 patients were evaluated to assess the efficacy of TBO and a diode laser in combination with the conventional root canal treatment. ${ }^{26}$ The results showed a $96.7 \%$ bacterial reduction. ${ }^{26}$ Another study by the same authors included 64 patients and used a chelating agent (ethylenediaminetetraacetic acid EDTA) before the use of LAD. ${ }^{27}$ The results also showed 
a significant bacterial reduction. ${ }^{27}$ Garcez et al. conducted a study on 20 patients and the initial exposure to LAD resulted in a $98.5 \%$ bacterial reduction. ${ }^{28}$ The treatment was followed up with a calcium hydroxide $\left(\mathrm{Ca}(\mathrm{OH})_{2}\right)$ dressing for 1 week before another round of LAD exposure, resulting in a $99.9 \%$ bacterial killing rate. The authors suggested that the use of LAD before and after $\mathrm{Ca}(\mathrm{OH})_{2}$ was more effective than the initial dosage. ${ }^{28}$

Previous studies have shown that typical LAD parameters for the effective killing of microbes are on the order of $15 \mathrm{~J} / \mathrm{cm}^{2}$ delivered using a visible red diode laser with an output power of up to $100 \mathrm{~mW}$ over $60-120 \mathrm{~s}^{17,29-32}$ Lee et al. provided certain guidelines for the use of LAD in a clinical environment. ${ }^{33}$ They suggest that PS should be placed in direct contact with the infected site for a short period, allowing the microorganism to absorb as much of the reactive agent as possible. This would increase sensitivity to light. Also, the dye must be agitated within the canal to eliminate air bubbles that could impede contact with the bacteria. ${ }^{33}$ The photosensitizer must also be applied into a root canal space that is free of blood and saliva, as these can potentially impair the efficacy of photosensitization. ${ }^{34}$ In addition, to achieve maximal effects of the laser energy, it should be delivered through a diffuser tip, thus providing a narrow cylindrical pattern of light emission. ${ }^{33}$ The emission pattern also follows the shape of the root canal. ${ }^{33}$ Diffuser tips reduce power density, which, in turn, reduces the risk of optical injury. ${ }^{33}$

A study measuring a temperature rise in the root canal during $\mathrm{LAD}$ reported a value of $0.16 \pm 0.08^{\circ} \mathrm{C}$. ${ }^{35}$ This is lower than the reported $7^{\circ} \mathrm{C}$ safety level for periodontal injury. ${ }^{35}$ Another study measuring thermal effects during LAD suggested that a change in temperature was less than $0.5^{\circ} \mathrm{C} .{ }^{17}$ This change was not said to be clinically significant, since the critical threshold levels for irreversible pulpitis is 11 times higher, at $5.5^{\circ} \mathrm{C} .{ }^{35}$ This seems to suggest that, with regard to the concerns about the adverse effects due to a rise in temperature in the root canal, using LAD for endodontic disinfection can be considered harmless to the surrounding periodontal tissues. ${ }^{35}$

\section{Strategies to maximize bacterial killing by LAD}

\section{Pre-treatment of cells with membrane permeabilizing agents}

Nitzan et al. and other researchers suggested that the application of polycationic polypeptide polymyxin $\mathrm{B}$ nonapeptide (PMBN) prior to LAD exposure increased the permeability of the outer cell membrane of various Gramnegative bacteria. ${ }^{36-39}$ This treatment allows a greater penetration of the photosensitizing agent in situations where the supply of ROS is low. The application of PMBN does not cause the release of lipopolysaccharides (LPSs) from the cell; rather it causes the outer membrane to expand, resulting in an increased penetration of PS. A study by Walther et al. concluded that following pre-treatment with PMBN, Gram-negative Yersinia pseudotuberculosis and Escherichia coli had an increased susceptibility to a combination of LAD exposure and protochlorophyllide. ${ }^{40}$ In a similar approach, Yonei and Todo showed that the lethal effects of EDTA increased when the $E$. coli samples were exposed to LAD beforehand. ${ }^{41}$ This may be due to the presence of chlorpromazine in EDTA. ${ }^{41}$ Also, EDTA can stimulate the release of LPSs in E. coli treated with calcium chloride $\left(\mathrm{CaCl}_{2}\right)$ when LAD is used with either rose bengal or hematoporphyrin/zinc phthalocyanines. ${ }^{42}$

\section{Modification of the photosensitizer}

In a study by Bezman et al., the authors were able to covalently bind rose bengal to polystyrene beads mixed in a bacterial suspension. ${ }^{43}$ The authors concluded that this approach enabled PS to form ROS that could penetrate more easily and efficiently through the outer cell membrane. ${ }^{43}$ This is similar to the work by Friedberg et al., who were able to bind PSs to monoclonal antibodies. ${ }^{44}$ These antibodies could attach themselves to the surface antigens present on Pseudomonas aeruginosa, which resulted in the specific killing of the target bacteria. ${ }^{44}$ Wilson applied phenothiazinium TBO and LAD on a variety of both Gram-positive and Gram-negative bacteria, achieving significant eradication rates. ${ }^{45}$ Similar results were reported by Usacheva et al. ${ }^{46}$ and George and Kishen, ${ }^{47}$ where the authors used phenothiazinium dyes to inactivate Grampositive and Gram-negative bacteria.

Soukos et al. suggested that it might be possible to covalently bond a photosensitizing agent to a poly-L-lysine chain. ${ }^{48}$ This delivery vehicle could effectively inactivate a variety of bacterial species. The authors demonstrated that by conjugating chlorine e 6 and a poly-L-lysine chain made up of 20 lysine molecules, a killing rate of over $99 \%$ for Actinomyces viscosus (Gram-positive) and Porphyromonas gingivalis (Gram-negative) could be achieved. ${ }^{48}$ Similar results were reported by Rovaldi et al., where the authors used a construct of 1 chlorine e6 and a 5-amino acid lysine chain, ${ }^{49}$ and by Hamblin et al., where the authors described the effects of a poly-L-lysine-chlorine e6 conjugate of 37 lysines bound with 1 chlorine e 6 molecule against both Gram-positive and Gram-negative species, achieving a significantly high killing rate. ${ }^{50}$

\section{5-ALA porphyrin stimulation}

Kennedy and Pottier reported the possibility of increasing the amount of porphyrins present in bacterial species that do not have the natural tendency to produce endogenous porphyrins. ${ }^{51}$ This was achieved by adding exogenous 5-aminolevulinic acid (5-ALA). ${ }^{51}$ The inactivation 
of $E$. coli after incubation in 5-ALA and exposure to white light was shown by Gábor et al. ${ }^{52}$ However, Enterococcus hirae could not be eradicated with this approach. ${ }^{52}$

\section{Alteration of the photosensitizer}

Studies have also been conducted to improve the efficacy of the LAD process. ${ }^{53,54}$ George and Kishen mixed $\mathrm{MB}$ with water, $70 \%$ glycerol, and $70 \%$ polyethylene gly$\mathrm{col}$ (PEG) in a proportion of glycerol:ethanol:water (MIX) of 30:20:50. ${ }^{47}$ Their results indicated that the molecules of $\mathrm{MB}$ aggregated at a greater rate in ${ }^{1} \mathrm{O}_{2}$ water as compared to the other aqueous media. The combination of MB with the MIX formulation produced greater bactericidal activity. This is believed to be due to a combined effect of an increased penetration of MIX within the dentinal tubules, the enhanced photooxidation of the model substrate and an increased rate of production of ${ }^{1} \mathrm{O}_{2} \cdot{ }^{47}$ A follow-up study suggested that, when compared with water, MIX resulted in an increased level of damage to the cell wall and chromosomal DNA. ${ }^{55}$ The same authors also indicted that the alteration of the formula by the addition of an oxidizing agent and $\mathrm{O}_{2}$ resulted in a more efficient disinfection of the endodontic biofilm. ${ }^{55}$ The altered emulsion was composed of perfluoro(decahydronaphtha lene) (oxygen carrier) and hydrogen peroxide (oxidizer) mixed with the detergent Triton ${ }^{\circledR}-\mathrm{X} 100 . .^{55}$

\section{Efflux pump inhibitors}

Prokaryotic and eukaryotic families have membrane proteins called "efflux pumps", which aid in the removal of amphiphilic molecules from the cell. ${ }^{56}$ These molecules combine hydrophobic properties, which facilitate cell penetration, and hydrophilic properties, which allow the distribution of compounds to tissues within the body. Many of the drugs available are amphiphilic; hence, efflux pumps tend to remove these molecules effectively from the cell. ${ }^{57}$ Efflux is suggested to be a significant contributor toward bacterial survival (Fig. 3). ${ }^{58}$ Inhibiting this process could potentially restore the ability of antimicrobials to decrease bacterial resistance. Kvist et al. indicated that efflux pumps were generally highly active within biofilms, therefore making them good targets to help prevent biofilm formation. ${ }^{59}$

In addition, the amphipathic cations have an inhibitory effect on efflux pumps; therefore, phenothiazinium dyes can act as substrates for the microbial efflux pumps, as they are structurally similar to the amphipathic cations. ${ }^{60}$ Indeed, it has been demonstrated that the inhibition of efflux pumps, along with phenothiazinium dyes, increases the efficacy of LAD. ${ }^{61}$ However, there are no current clinical applications using these efflux pump inhibitors. This could be due to the increased levels of toxicity observed with these compounds, which has been reported in animal studies. ${ }^{62}$

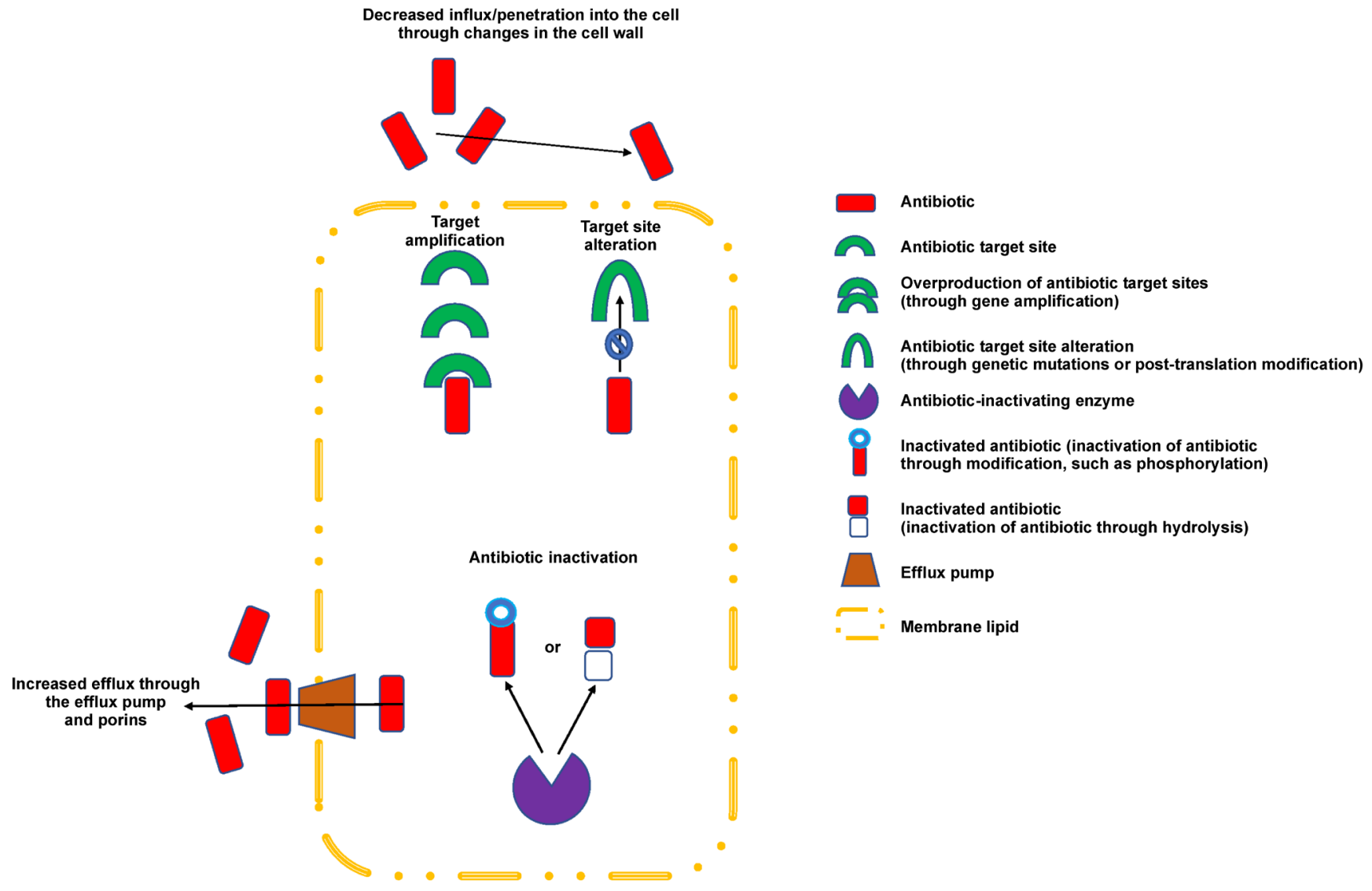

Fig. 3. Schematic diagram highlighting the efflux pump antibiotic resistance mechanisms utilized by bacteria 


\section{Factors limiting the efficacy of LAD}

The light source is a limiting factor for the penetrative ability of LAD. Light can be either coherent (lasers) or non-coherent (lamps). ${ }^{63}$ The type of light required is dependent on the location, dosage, and PSs or porphyrins being used. Lasers provide powerful monochromatic light that reduces the delivery time of LAD. As lasers are monochromatic, the wavelength plays a crucial role in the LAD process, as it should match the absorption bands of PSs or porphyrins. ${ }^{63}$ This often means that a combination of different lasers may be required to achieve the desired result. The laser systems used in various LAD studies include argon (Ar)/dye lasers, He-Ne lasers, potassium titanyl phosphate/neodymium-doped yttrium aluminum garnet (KTP/Nd:YAG)/dye lasers, and diode lasers (Table 1 and Table 2). Presently, lasers are the source of choice when used to irradiate areas accessible only with the aid of optical fibers. The beam quality and the output power are characteristics that make lasers highly effective when coupled with optical fiber cores smaller than $500 \mu \mathrm{m}$ in diameter. ${ }^{63}$

In comparison to lasers, lamps cannot be used in combination with small optical fibers, as their poor beam quality, large beam size and low power densities make them inefficient for use in smaller areas. Lamps, however, can be used directly or coupled with a liquid light guide of $5-10 \mathrm{~mm}$ in diameter. Both lamps and lasers have been used in LAD and neither is shown to be better than the other based on their application. Although LAD has been traditionally performed using lasers, the availability of broad-band sources (lamps) is challenging the use of lasers. ${ }^{63}$ The scattering of light in tissues has a pronounced effect on light intensity and directionality. Along with refraction, it causes a widening of the light beam, thus lowering the fluence rate (energy per unit area) of the light, which results in a change of the direction of the light. Williams et al. used LAD combined with TBO on S. intermedius with a diode laser at $633 \mathrm{~nm}$ and an output power of $80 \mathrm{~mW} .^{24}$ The organism was irradiated for $30 \mathrm{~s}, 60 \mathrm{~s}$ and $90 \mathrm{~s}$ at energy doses of $2.4 \mathrm{~J}, 4.8 \mathrm{~J}$ and $7.2 \mathrm{~J}$, respectively. The authors concluded that the effectiveness of LAD increased with an increase in the dosage of energy. ${ }^{24}$ However, care must be taken, as the extensive use of light in this range could be harmful for the host cells.

\section{Conclusions}

Light-based disinfection is a promising novel approach for root canal disinfection, as studies have indicated its effectiveness against a vast majority of pathogens, including Gram-negative and Gram-positive bacteria. Light-activated disinfection targets multiple sites within the bacterial cell, therefore limiting the ability of the pathogens to acquire resistance. Moreover, it has been suggested that

Table 1. Light and dye parameters applied in some in vitro studies on the use of LAD in endodontics

\begin{tabular}{|c|c|c|c|c|}
\hline $\begin{array}{l}\text { Study } \\
\text { (year) }\end{array}$ & Model & $\begin{array}{l}\text { Light and } \\
\text { irradiation parameters }\end{array}$ & $\begin{array}{l}\text { Photosensitizer } \\
\text { (formula) }\end{array}$ & Results \\
\hline $\begin{array}{l}\text { Seal et al. } \\
(2002)^{18}\end{array}$ & $\begin{array}{l}\text { 2-day biofilms } \\
\text { of Staphylococcus intermedius }\end{array}$ & $\begin{array}{l}\text { He-Ne gas laser at } 632.8 \mathrm{~nm} \\
\qquad \mathrm{P}=35 \mathrm{~mW} \\
\mathrm{E}=2.1,3.2,4.2,10.5, \text { or } 21 \mathrm{~J}\end{array}$ & $\begin{array}{c}\mathrm{TBO} \\
\left(\mathrm{C}_{15} \mathrm{H}_{16} \mathrm{~N}_{3} \mathrm{~S}^{+}\right)\end{array}$ & $\begin{array}{l}\text { maximum of } 5 \log 10 \text { reduction } \\
\text { in CFU/mL at } 21 \mathrm{~J}\end{array}$ \\
\hline $\begin{array}{l}\text { Soukos et al. } \\
(2006)^{23}\end{array}$ & $\begin{array}{l}\text { 3-day biofilms } \\
\text { of Enterococcus faecalis }\end{array}$ & $\begin{array}{l}\text { diode laser at } 665 \mathrm{~nm} \\
\mathrm{PD}=740 \mathrm{~mW} / \mathrm{cm}^{2} \\
\mathrm{~F}=222 \mathrm{~J} / \mathrm{cm}^{2}\end{array}$ & $\begin{array}{c}\mathrm{MB} \\
\left(\mathrm{C}_{16} \mathrm{H}_{18} \mathrm{CIN} \mathrm{N}_{3} \mathrm{~S}\right)\end{array}$ & $\begin{array}{l}97 \% \text { reduction } \\
\text { in bacterial viability }\end{array}$ \\
\hline $\begin{array}{l}\text { George and Kishen } \\
(2007)^{21}\end{array}$ & $\begin{array}{l}\text { 4-day biofilms of E. faecalis } \\
\text { and Aggregatibacter } \\
\text { actinomycetemcomitans }\end{array}$ & $\begin{array}{c}\text { diode laser at } 664 \mathrm{~nm} \\
\qquad \begin{array}{c}P=30 \mathrm{~mW} \\
\mathrm{E}=36 \mathrm{~J}\end{array}\end{array}$ & $\begin{array}{c}\mathrm{MB} \\
\left(\mathrm{C}_{16} \mathrm{H}_{18} \mathrm{ClN} \mathrm{N}_{3} \mathrm{~S}\right)\end{array}$ & $\begin{array}{l}\geq 5 \log 10 \text { reduction } \\
\text { in CFU/mL }\end{array}$ \\
\hline $\begin{array}{l}\text { Fonseca et al. } \\
(2008)^{19}\end{array}$ & $\begin{array}{l}\text { 2-day biofilms } \\
\text { of } E \text {. faecalis }\end{array}$ & $\begin{array}{l}\text { Ga-Al-As diode laser } \\
\qquad \begin{array}{c}P=50 \mathrm{~mW} \\
E=6.4 \mathrm{~J}\end{array}\end{array}$ & $\begin{array}{c}\mathrm{TBO} \\
\left(\mathrm{C}_{15} \mathrm{H}_{16} \mathrm{~N}_{3} \mathrm{~S}^{+}\right)\end{array}$ & $\begin{array}{l}\approx 99.9 \% \text { reduction } \\
\text { in bacterial viability }\end{array}$ \\
\hline $\begin{array}{l}\text { Fimple et al. } \\
(2008)^{22}\end{array}$ & 3-day multi-species biofilm & $\begin{array}{l}\text { diode laser at } 665 \mathrm{~nm} \\
\mathrm{PD}=100 \mathrm{~mW} / \mathrm{cm}^{2} \\
F=30 \mathrm{~J} / \mathrm{cm}^{2}\end{array}$ & $\begin{array}{c}\mathrm{MB} \\
\left(\mathrm{C}_{16} \mathrm{H}_{18} \mathrm{ClN}_{3} \mathrm{~S}\right)\end{array}$ & $\begin{array}{l}\approx 73-80 \% \text { reduction } \\
\text { in bacterial viability }\end{array}$ \\
\hline $\begin{array}{l}\text { Meire et al. } \\
(2009)^{20}\end{array}$ & $\begin{array}{l}\text { 2-day biofilms } \\
\text { of } E \text {. faecalis }\end{array}$ & $\begin{array}{c}\text { diode laser at } 635 \mathrm{~nm} \\
P=100 \mathrm{~mW} \\
E=15 \mathrm{~J}\end{array}$ & $\begin{array}{c}\mathrm{TBO} \\
\left(\mathrm{C}_{15} \mathrm{H}_{16} \mathrm{~N}_{3} \mathrm{~S}^{+}\right)\end{array}$ & $\approx 1.5 \log 10$ reduction in CFU/mL \\
\hline $\begin{array}{l}\text { Aydin et al. } \\
(2020)^{65}\end{array}$ & $\begin{array}{l}\text { 28-day incubation } \\
\text { of } E \text {. faecalis }\end{array}$ & $\begin{array}{l}\text { diode laser at } 628 \mathrm{~nm} \\
\mathrm{P} \text { - not mentioned }\end{array}$ & $\begin{array}{c}\mathrm{TBO} \\
\left(\mathrm{C}_{15} \mathrm{H}_{16} \mathrm{~N}_{3} \mathrm{~S}^{+}\right)\end{array}$ & $\begin{array}{l}\text { 97.8911\% reduction } \\
\text { in E. faecalis bacterial load }\end{array}$ \\
\hline $\begin{array}{l}\text { Yoshii et al. } \\
(2021)^{64}\end{array}$ & $\begin{array}{l}\text { 2-day biofilms } \\
\text { of Lactobacillus acidophilus }\end{array}$ & $\begin{array}{l}\text { laser at } 650 \text { and } 940 \mathrm{~nm} \\
\mathrm{P}=9 \mathrm{~mW} \text { and } 600 \mathrm{~mW} \\
\mathrm{E}-\text { not mentioned }\end{array}$ & $\begin{array}{c}\mathrm{AR} \\
\left(\mathrm{C}_{27} \mathrm{H}_{29} \mathrm{~N}_{2} \mathrm{NaO}_{7} \mathrm{~S}_{2}\right) \\
\text { and } \\
\mathrm{BB} \\
\left(\mathrm{C}_{37} \mathrm{H}_{34} \mathrm{~N}_{2} \mathrm{Na}_{2} \mathrm{O}_{9} \mathrm{~S}_{3}\right)\end{array}$ & $\begin{array}{l}\text { 650-nm laser combined with the BB } \\
\text { solution was most effective in sterilizing } \\
\text { the dentin plates infected with } \\
\text { L.acidophilus }\end{array}$ \\
\hline
\end{tabular}

He-Ne - helium-neon; P - output power; E - energy; PD - power density; F - fluence; Ga-Al-As - gallium-aluminum-arsenide; TBO - toluidine blue O; $\mathrm{MB}$ - methylene blue; $\mathrm{AR}$ - acid red; $\mathrm{BB}$ - brilliant blue; CFU - colony-forming unit. 
Table 2. Light and dye parameters applied in some in vivo studies on the use of LAD in endodontics

\begin{tabular}{|c|c|c|c|c|}
\hline $\begin{array}{l}\text { Study } \\
\text { (year) }\end{array}$ & Model & $\begin{array}{l}\text { Light and } \\
\text { irradiation parameters }\end{array}$ & $\begin{array}{l}\text { Photosensitizer } \\
\text { (formula) }\end{array}$ & Results \\
\hline $\begin{array}{l}\text { Bonsor et al. } \\
(2006)^{27}\end{array}$ & $\begin{array}{l}64 \text { canals in patients with } \\
\text { symptoms of irreversible } \\
\text { pulpitis/apical periodontitis }\end{array}$ & $\begin{array}{c}\text { diode laser at } 633 \mathrm{~nm} \\
\qquad \begin{array}{c}P=100 \mathrm{~mW} \\
E=12 \mathrm{~J}\end{array}\end{array}$ & $\begin{array}{c}\mathrm{TBO} \\
\left(\mathrm{C}_{15} \mathrm{H}_{16} \mathrm{~N}_{3} \mathrm{~S}^{+}\right)\end{array}$ & $\begin{array}{l}\quad>90 \% \text { reduction } \\
\text { in bacterial viability with the use } \\
\text { of a chelating agent along with LAD }\end{array}$ \\
\hline $\begin{array}{l}\text { Garcez et al. } \\
(2008)^{28}\end{array}$ & $\begin{array}{l}20 \text { single-rooted canals } \\
\text { in patients with symptoms } \\
\text { of necrotic pulp and apical } \\
\text { periodontitis }\end{array}$ & $\begin{array}{l}\text { diode laser at } 660 \mathrm{~nm} \\
\qquad \begin{array}{c}P=40 \mathrm{~mW} \\
E=9.6 \mathrm{~J}\end{array}\end{array}$ & $\begin{array}{c}\text { PEl } \\
\left(\mathrm{C}_{2} \mathrm{H}_{5} \mathrm{~N}\right)_{n} \\
\text { and } \\
\text { chlorin e6 } \\
\left(\mathrm{C}_{34} \mathrm{H}_{36} \mathrm{~N}_{4} \mathrm{O}_{6}\right) \\
\text { conjugate }\end{array}$ & $\begin{array}{l}\qquad \begin{array}{l}\approx 99.9 \% \text { reduction } \\
\text { in bacterial viability following } \\
2 \text { successive combinations }\end{array} \\
\text { of the conventional endodontic therapy and LAD }\end{array}$ \\
\hline $\begin{array}{l}\text { Zorita-García et al. } \\
(2019)^{66}\end{array}$ & $\begin{array}{c}42 \text { single-rooted teeth } \\
\text { in } 33 \text { patients with apical } \\
\text { periodontitis }\end{array}$ & $\begin{array}{l}\text { diode laser at } 630 \mathrm{~nm} \\
\mathrm{PD}=2,000 \mathrm{~mW} / \mathrm{cm}^{2}\end{array}$ & $\begin{array}{c}\mathrm{TBO} \\
\left(\mathrm{C}_{15} \mathrm{H}_{16} \mathrm{~N}_{3} \mathrm{~S}^{+}\right)\end{array}$ & $\begin{array}{l}90.3 \% \text { reduction } \\
\text { in E. faecalis bacterial load }\end{array}$ \\
\hline
\end{tabular}

$\mathrm{PEI}$ - polyethylenimine

LAD can be used either as a substitute or an adjunct to the conventional antimicrobial treatment regimens used for battling polymicrobial biofilms. However, it is the authors' suggestion that further studies be conducted, e.g., incorporating nanocarrier systems for PS to evaluate its effect on various biofilms that are persistent in root canal infections.

\section{ORCID iDs}

Saad Haroon (1) https://orcid.org/0000-0002-6799-0243

Abdul Khabeer (1) https://orcid.org/0000-0001-5372-6807

Muhammad Ali Faridi (i) https://orcid.org/0000-0002-4461-339X

\section{References}

1. Paster BJ, Dewhirst FE. Phylogenetic foundation of spirochetes. J Mol Microbiol Biotechnol. 2000;2(4):341-344.

2. Sundqvist G. Taxonomy, ecology, and pathogenicity of the root canal flora. Oral Surg Oral Med Oral Pathol. 1994;78(4):522-530. doi:10.1016/0030-4220(94)90047-7

3. Radcliffe CE, Potouridou L, Qureshi R, et al. Antimicrobial activity of varying concentrations of sodium hypochlorite on the endodontic microorganisms Actinomyces israelii, A. naeslundii, Candida albicans and Enterococcus faecalis. Int Endod J. 2004;37(7):438-446. doi:10.1111/j.1365-2591.2004.00752.x

4. Sainudeen S, Nair VS, Zarbah M, Abdulla AM, Najeeb CM, Ganapathy S. Can herbal extracts serve as antibacterial root canal irrigating solutions? Antimicrobial efficacy of Tylophora indica, Curcumin longa, Phyllanthus amarus, and sodium hypochlorite on Enterococcus faecalis biofilms formed on tooth substrate: In vitro study. J Pharm Bioallied Sci. 2020;12(Suppl 1):S423-S429. doi:10.4103/jpbs.JPBS_127_20

5. Ricucci D, Lopes WSP, Loghin S, Rôças IN, Siqueira JF Jr. Large bacterial floc causing an independent extraradicular infection and posttreatment apical periodontitis: A case report. J Endod. 2018;44(8):1308-1316. doi:10.1016/j.joen.2018.05.009

6. Friedman S. Prognosis of healing in treated teeth with endodontic infections. In: Fouad AF, ed. Endodontic Microbiology. $2^{\text {nd }}$ ed. Hoboken, USA: John Wiley \& Sons; 2017:341-384.

7. Ricucci $D$, Siqueira JF Jr. Biofilms and apical periodontitis: Study of prevalence and association with clinical and histopathologic findings. J Endod. 2010;36(8):1277-1288. doi:10.1016/j.joen.2010.04.007

8. Nakamura VC, Pinheiro ET, Prado LC, et al. Effect of ultrasonic activation on the reduction of bacteria and endotoxins in root canals: A randomized clinical trial. Int Endod J. 2018;51(Suppl 1):e12-e22. doi:10.1111/iej.12783

9. Sunde PT, Olsen I, Göbel UB, et al. Fluorescence in situ hybridization (FISH) for direct visualization of bacteria in periapical lesions of asymptomatic root-filled teeth. Microbiology (Reading). 2003;149(Pt 5):1095-1102. doi:10.1099/mic.0.26077-0
10. Wang Z, Shen Y, Haapasalo M. Effectiveness of endodontic disinfecting solutions against young and old Enterococcus faecalis biofilms in dentin canals. J Endod. 2012;38(10):1376-1379. doi:10.1016/j.joen.2012.06.035

11. Gulabivala K, Ng YL, Gilbertson M, Eames I. The fluid mechanics of root canal irrigation. Physiol Meas. 2010;31(12):R49-R84. doi:10.1088/0967-3334/31/12/R01

12. Mazzoni A, Pacifici A, Zanza A, et al. Assessment of real-time operative torque during nickel-titanium instrumentation with different lubricants. App/ Sci. 2020;10(18):6201. doi:10.3390/app10186201

13. McDonnell G, Russell AD. Antiseptics and disinfectants: Activity, action, and resistance. Clin Microbiol Rev. 1999;12(1):147-179.

14. Spratt DA, Pratten J, Wilson M, Gulabivala K. An in vitro evaluation of the antimicrobial efficacy of irrigants on biofilms of root canal isolates. Int Endod J. 2001;34(4):300-307. doi:10.1046/j.1365-2591.2001.00392.x

15. Foote CS. Definition of type I and type II photosensitized oxidation. Photochem Photobiol. 1991;54(5):659. doi:10.1111/j.1751-1097.1991. tb02071.x

16. Wainwright M. Photodynamic antimicrobial chemotherapy (PACT). J Antimicrob Chemother. 1998;42(1):13-28. doi:10.1093/jac/42.1.13

17. Walsh $L J$. The current status of laser applications in dentistry.Aust DentJ. 2003;48(3):146-155;quiz 198. doi:10.1111/j.1834-7819.2003.tb00025.x

18. Seal GJ, Ng YL, Spratt D, Bhatti M, Gulabivala K. An in vitro comparison of the bactericidal efficacy oflethal photosensitization or sodium hyphochlorite irrigation on Streptococcus intermedius biofilms in root canals. Int Endod J. 2002;35(3):268-274. doi:10.1046/j.1365-2591.2002.00477.x

19. Fonseca MB, Tessare PO Jr., Pallota RC, et al. Photodynamic therapy for root canals infected with Enterococcus faecalis. Photomed Laser Surg. 2008;26(3):209-213. doi:10.1089/pho.2007.2124

20. Meire MA, De Prijck K, Coenye T, Nelis HJ, De Moor RJG. Effectiveness of different laser systems to kill Enterococcus faecalis in aqueous suspension and in an infected tooth model. Int Endod J. 2009;42(4):351-359. doi:10.1111/j.1365-2591.2008.01532.x

21. George S, Kishen A. Photophysical, photochemical, and photobiological characterization of methylene blue formulations for light-activated root canal disinfection. J Biomed Opt. 2007;12(3):034029. doi:10.1117/1.2745982

22. Fimple JL, Fontana CR, Foschi F, et al. Photodynamic treatment of endodontic polymicrobial infection in vitro. J Endod. 2008;34(6):728-734. doi:10.1016/j.joen.2008.03.011

23. Soukos NS, Chen PSY, Morris JT, et al. Photodynamic therapy for endodontic disinfection. J Endod. 2006;32(10):979-984. doi:10.1016/j.joen.2006.04.007

24. Williams JA, Pearson GJ, Colles MJ. Antibacterial action of photoactivated disinfection (PAD) used on endodontic bacteria in planktonic suspension and in artificial and human root canals. J Dent. 2006;34(6):363-371. doi:10.1016/j.jdent.2005.08.002

25. van Winkelhoff AJ, Carlee AW, de Graaff J. Bacteroides endodontalis and other black-pigmented Bacteroides species in odontogenic abscesses. Infect Immun. 1985;49(3):494-497. doi:10.1128/ iai.49.3.494-497.1985

26. Bonsor SJ, Nichol R, Reid TMS, Pearson GJ. An alternative regimen for root canal disinfection. Br Dent J. 2006;201(2):101-105; discussion 98;quiz 120. doi:10.1038/sj.bdj.4813819 
27. Bonsor SJ, Nichol R, Reid TMS, Pearson GJ. Microbiological evaluation of photo-activated disinfection in endodontics (an in vivo study). BrDent J. 2006;200(6):337-341;discussion 329. doi:10.1038/sj.bdj.4813371

28. Garcez AS, Nuñez SC, Hamblin MR, Ribeiro MS. Antimicrobial effects of photodynamic therapy on patients with necrotic pulps and periapical lesion. J Endod. 2008;34(2):138-142. doi:10.1016/j.joen.2007.10.020

29. Abdelaziz Ali IA, Neelakantan P. Light activated disinfection in root canal treatment - a focused review. Dent J (Basel). 2018;6(3):31. doi:10.3390/dj6030031

30. Pagonis TC, Chen J, Fontana CR, et al. Nanoparticle-based endodontic antimicrobial photodynamic therapy. J Endod. 2010;36(2):322-328. doi:10.1016/j.joen.2009.10.011

31. Vecchio D, Gupta A, Huang L, et al. Bacterial photodynamic inactivation mediated by methylene blue and red light is enhanced by synergistic effect of potassium iodide. Antimicrob Agents Chemother. 2015;59(9):5203-5212. doi:10.1128/AAC.00019-15

32. Yin R, Dai T, Avci P, et al. Light based anti-infectives: Ultraviolet $C$ irradiation, photodynamic therapy, blue light, and beyond. Curr Opin Pharmacol. 2013;13(5):731-762. doi:10.1016/j.coph.2013.08.009

33. Lee MT, Bird PS, Walsh LJ. Photo-activated disinfection of the root canal: A new role for lasers in endodontics. Aust Endod J. 2004;30(3):93-98. doi:10.1111/j.1747-4477.2004.tb00417.x

34. Wilson M, Pratten J. Lethal photosensitisation of Staphylococcus aureus in vitro: Effect of growth phase, serum, and pre-irradiation time. Lasers Surg Med. 1995;16(3):272-276. doi:10.1002/lsm.1900160309

35. Dickers B, Lamard L, Peremans A, et al. Temperature rise during photo-activated disinfection of root canals. Lasers Med Sci. 2009;24(1):81-85. doi:10.1007/s10103-007-0526-y

36. Nitzan Y, Gutterman M, Malik Z, Ehrenberg B. Inactivation of gramnegative bacteria by photosensitized porphyrins. Photochem Photobiol. 1992;55(1):89-96. doi:10.1111/j.1751-1097.1992.tb04213.x

37. Galstyan A. Turning photons into drugs: Phthalocyanine-based photosensitizers as efficient photoantimicrobials. Chemistry. 2021;27(6):1903-1920. doi:10.1002/chem.202002703

38. Ucuncu M, Mills B, Duncan S, Staderini M, Dhaliwal K, Bradley M. Polymyxin-based photosensitizer for the potent and selective killing of Gram-negative bacteria. Chem Commun (Camb). 2020;56(26):3757-3760. doi:10.1039/d0cc00155d

39. Garcia de Carvalho G, Sanchez-Puetate JC, Donatoni MC, et al Photodynamic inactivation using a chlorin-based photosensitizer with blue or red-light irradiation against single-species biofilms related to periodontitis. Photodiagnosis Photodyn Ther. 2020;31:101916. doi:10.1016/j.pdpdt.2020.101916

40. Walther J, Bröcker MJ, Wätzlich D, et al. Protochlorophyllide: $A$ new photosensitizer for the photodynamic inactivation of Gram-positive and Gram-negative bacteria. FEMS Microbiol Lett. 2009;290(2):156-163. doi:10.1111/j.1574-6968.2008.01413.x

41. Yonei $S$, Todo T. Enhanced sensitivity to the lethal and mutagenic effects of photosensitizing action of chlorpromazine in ethylenediaminetetraacetate-treated Escherichia coli. Photochem Photobiol. 1982;35(4):591-592. doi:10.1111/j.1751-1097.1982.tb02616.x

42. Valduga G, Bertoloni G, Reddi E, Jori G. Effect of extracellularly generated singlet oxygen on gram-positive and gram-negative bacteria. J Photochem Photobiol B. 1993;21(1):81-86. doi:10.1016/10111344(93)80168-9

43. Bezman SA, Burtis PA, Izod TP, Thayer MA. Photodynamic inactivation of $E$. coli by rose bengal immobilized on polystyrene beads. Photochem Photobiol. 1978;28(3):325-329. doi:10.1111/j.1751-1097.1978.tb07714.x

44. Friedberg JS, Tompkins RG, Rakestraw SL, Warren SW, Fischman AJ, Yarmush ML. Antibody-targeted photolysis. Bacteriocidal effects of Sn (IV) chlorin e6-dextran-monoclonal antibody conjugates. Ann NY Acad Sci. 1991;618:383-393. doi:10.1111/j.1749-6632.1991.tb27258.x

45. Wilson M. Photolysis of oral bacteria and its potential use in the treatment of caries and periodontal disease. J Appl Microbiol. 1993;75(4):299-306. doi:10.1111/j.1365-2672.1993.tb02780.x

46. Usacheva MN, Teichert MC, Biel MA. The role of the methylene blue and toluidine blue monomers and dimers in the photoinactivation of bacteria. J Photochem Photobiol B. 2003;71(1-3):87-98. doi:10.1016/j.jphotobiol.2003.06.002

47. George S, Kishen A. Advanced noninvasive light-activated disinfection: Assessment of cytotoxicity on fibroblast versus antimicrobial activity against Enterococcus faecalis. J Endod. 2007;33(5):599-602. doi:10.1016/j.joen.2007.01.018
48. Soukos NS, Hamblin MR, Hasan T. The effect of charge on cellular uptake and phototoxicity of polylysine chlorin(e6) conjugates. Photochem Photobiol. 1997;65(4):723-729. doi:10.1111/j.1751-1097.1997.tb01916.x

49. Rovaldi CR, Pievsky A, Sole NA, Friden PM, Rothstein DM, Spacciapoli P. Photoactive porphyrin derivative with broad-spectrum activity against oral pathogens in vitro. Antimicrob Agents Chemother. 2000;44(12):3364-3367. doi:10.1128/AAC.44.12.3364-3367.2000

50. Hamblin MR, O'Donnell DA, Murthy N, et al. Polycationic photosensitizer conjugates: Effects of chain length and Gram classification on the photodynamic inactivation of bacteria. J Antimicrob Chemother. 2002;49(6):941-951. doi:10.1093/jac/dkf053

51. Kennedy JC, Pottier RH. Endogenous protoporphyrin IX, a clinically useful photosensitizer for photodynamic therapy. J Photochem Photobiol B. 1992;14(4):275-292. doi:10.1016/1011-1344(92)85108-7

52. Gábor F, Szocs K, Maillard P, Csík G. Photobiological activity of exogenous and endogenous porphyrin derivatives in Escherichia coli and Enterococcus hirae cells. Radiat Environ Biophys. 2001;40(2):145-151. doi:10.1007/s004110100092

53. Ahangari Z, Bidabadi MM, Asnaashari M, Rahmati A, Tabatabaei FS. Comparison of the antimicrobial efficacy of calcium hydroxide and photodynamic therapy against Enterococcus faecalis and Candida albicans in teeth with periapical lesions; an in vivo study. J Lasers Med Sci. 2017;8(2):72-78. doi:10.15171/jlms.2017.13

54. Mahmoudi H, Bahador A, Pourhajibagher M, Alikhani MY. Antimicrobial photodynamic therapy: An effective alternative approach to control bacterial infections. J Lasers Med Sci. 2018;9(3):154-160. doi:10.15171/jlms.2018.29

55. George S, Kishen A. Influence of photosensitizer solvent on the mechanisms of photoactivated killing of Enterococcus faecalis. Photochem Photobiol. 2008;84(3):734-740. doi:10.1111/j.1751-1097.2007.00244.x

56. Ryan BM, Dougherty TJ, Beaulieu D, Chuang J, Dougherty BA, Barrett JF. Efflux in bacteria: What do we really know about it? Expert Opin Investig Drugs. 2001;10(8):1409-1422. doi:10.1517/13543784.10.8.1409

57. Walmsley AR, Zhou T, Borges-Walmsley MI, Rosen BP. A kinetic model for the action of a resistance efflux pump. J Biol Chem. 2001;276(9):6378-6391. doi:10.1074/jbc.M008105200

58. Lewis K. In search of natural substrates and inhibitors of MDR pumps. J Mol Microbiol Biotechnol. 2001;3(2):247-254.

59. Kvist T, Molander A, Dahlén G, Reit C. Microbiological evaluation of one- and two-visit endodontic treatment of teeth with apical periodontitis: A randomized, clinical trial. J Endod. 2004;30(8):572-576. doi:10.1097/01.don.0000121607.87969.6e

60. Tegos GP, Hamblin MR. Phenothiazinium antimicrobial photosensitizers are substrates of bacterial multidrug resistance pumps. Antimicrob Agents Chemother. 2006;50(1):196-203. doi:10.1128/AAC.50.1.196-203.2006

61. Tegos GP, Masago K, Aziz F, Higginbotham A, Stermitz FR, Hamblin MR. Inhibitors of bacterial multidrug efflux pumps potentiate antimicrobial photoinactivation. Antimicrob Agents Chemother. 2008;52(9):3202-3209. doi:10.1128/AAC.00006-08

62. Lynch AS. Efflux systems in bacterial pathogens: An opportunity for therapeutic intervention? An industry view. Biochem Pharmacol. 2006;71(7):949-956. doi:10.1016/j.bcp.2005.10.021

63. Brancaleon L, Moseley $H$. Laser and non-laser light sources for photodynamic therapy. Lasers Med Sci. 2002;17(3):173-186. doi:10.1007/s101030200027

64. Yoshii D, Katsuragi H, Shinkai K. Bactericidal effect of antimicrobial photodynamic therapy (aPDT) on dentin plate infected with Lactobacillus acidophilus. Odontology. 2021;109(1):67-75. doi:10.1007/ s10266-020-00532-w

65. Aydin SA, Taşdemir T, Buruk CK, Çelik D. Efficacy of erbium, chromiumdoped yttrium, scandium, gallium and garnet laser-activated irrigation compared with passive ultrasonic irrigation, conventional irrigation, and photodynamic therapy against Enterococcus faecalis. J Contemp Dent Pract. 2020;21(1):11-16.

66. Zorita-García M, Alonso-Ezpeleta LÓ, Cobo M, et al. Photodynamic therapy in endodontic root canal treatment significantly increases bacterial clearance, preventing apical periodontitis. Quintessence Int. 2019;50(10):782-789. doi:10.3290/j.qi.a43249 